\title{
Cavitation erosion and sliding wear resistance of HVOF coatings
}

Keywords:

cavitation erosion;

sliding wear;

HVOF;

thermal spraying

\begin{abstract}
The aim of the work was to investigate the resistance to cavitation erosion and sliding wear of as-sprayed HVOF coatings. $\mathrm{M}(\mathrm{Ni}, \mathrm{Co}) \mathrm{CrAlY}$ and $\mathrm{Cr}_{3} \mathrm{C}_{2}-\mathrm{NiCr}$ based coatings were deposited using HVOF method onto stainless steel substrate grade AISI 304. As-sprayed coatings' surface morphology was examined by SEM-EDS and profilometer methods. Cavitation erosion tests were conducted in distilled water with the use of vibratory rig and stationary specimen method. Cavitation erosion curves were plotted as well as cavitational wear mechanism was observed with the use of SEM microscope. Sliding wear tests were performed using the ball-on-disc tribotester with counter-specimen (ball) made of steel 100Cr6. Wear rates and coefficient of friction were computed. Normalized wear resistance with reference to stainless steel reference sample AISI 304 was calculated. In addition, comparable analysis of wear resistance results was conducted. $\mathrm{M}(\mathrm{Ni}, \mathrm{Co}) \mathrm{CrAlY}$ coating presented the highest cavitation erosion resistance, therefore $\mathrm{Cr}_{3} \mathrm{C}_{2}-\mathrm{NiCr}$ coating represented the highest sliding wear resistance of all tested materials.
\end{abstract}

\section{Introduction}

Thermally sprayed coatings increase the wear resistance of machine and equipment components. The abrasive processes, erosion by solid particles and corrosion processes are the most frequently mentioned wear processes in literature $[1 \div 4$ ]. Systematic research articles on abrasive wear of thermally sprayed coatings are published and these issues seem to be quite well known. However, there are relatively few scientific reports describing issues related to the testing of resistance to cavitation wear of thermally sprayed coatings, using the HVOF (High Velocity Oxygen Fuel) method. The method is mainly used for metal or cermet coatings $[4 \div 10]$. In comparison to other thermal spraying processes, e.g. plasma spraying or flame spraying, HVOF spray coatings have a low porosity and homogeneous structure. This is mainly due to the low process temperature and the high speed of the sprayed particles $[2,11,12]$.

The search for coatings with high resistance to cavitation erosion is a current issue, both from a scientific and industrial point of view $[6,10,13 \div 15]$. Literature survey indicates that the homogeneous structure of the material has a positive effect on the increase in resistance to cavitation erosion [16 $\div 18]$.
Therefore, it seems advisable to carry out cavitation resistance tests of thermally sprayed coatings using the HVOF method. The literature describes works describing the resistance to cavitation wear of $\mathrm{Cr}_{3} \mathrm{C}_{2}$-NiCr cermet coatings applied with the HVOF method $[5,6]$, but there are few papers relating to resistance to cavitation erosion of MCrAlY ( $\mathrm{M}=\mathrm{Ni}$ and/or Co) type coatings. Particularly there is a lack of works which synthesize the results of the abrasive and cavitation tests of HVOF coatings carried out with reference to standard reference materials, for example stainless steel.

The aim of the research was to assess the resistance to cavitation erosion and abrasive wear of HVOF coatings.

\section{Material and methods of research}

The test material consisted of two thermally sprayed coatings with supersonic velocities (HVOF) on a stainless steel substrate of $\mathrm{AISI} 304$ grade (X5CrNi18-10 according to PN-EN), from which reference samples were made. Coatings of type $\mathrm{M}(\mathrm{Ni}, \mathrm{Co}) \mathrm{CrAlY}$ (designated as Z2) and $\mathrm{CrC}-\mathrm{NiCr}$ (designated

dr inż. Mirosław Szala - Lublin University of Technology, Mechanical Engineering Faculty, Lublin, Poland; dr hab. inż. Mariusz Walczak, prof. WSEI - University of Economics and Innovation, Lublin, Poland; 
as Z3) were sprayed onto steel pins with a diameter of $\varnothing 25$. $\mathrm{M}(\mathrm{Ni}, \mathrm{Co}) \mathrm{CrAlY}$ type thermally sprayed coatings are mainly used as bond-coatings, anti-oxidation and high temperature corrosion protection coatings, while $\mathrm{Cr}_{3} \mathrm{C}_{2}-\mathrm{NiCr}$ coatings are used to provide, among others, corrosion resistance, erosion resistance and abrasion resistance.

The morphology of the coatings was characterized by observing the surface using a Phenom World Pro-X scanning microscope (SEM-EDS, Phenom-World). The surface roughness of the coatings was measured after spraying using the Dektak 150 contact profilometer from Veeco Instruments, Inc. (rounding radius of the measuring needle $2 \mu \mathrm{m}$ ). An analysis of chemical composition was performed in selected micro-areas using the SEM-EDS method.

Cavitation tests were carried out using a vibratory apparatus using a stationary specimen method (in accordance with ASTM G-32). The distance between the tip of the sonotrode and the sample was $1 \mathrm{~mm}$. The tests were carried out in distilled water and the total test time was 12 hours. On the basis of successively determined with an accuracy of $0.1 \mathrm{mg}$ of mass loss, erosive curves of the tested materials were plotted. The qualitative analysis of the cavitation wear area of the HVOF spray coatings was performed. The worn surface was observed using the Phenom-World ProX scanning microscope, (15 kV, BSE detector, Phenom-World).

The abrasive wear tests were carried out on a CS-Instruments ball-on-disc tribotester. As a counter-sample (ball), a $6 \mathrm{~mm}$ diameter ball made of $100 \mathrm{Cr} 6$ steel with $64 \mathrm{HRC}$ hardness (from CSM Instruments) was used. The tests were carried out under a $5 \mathrm{~N}$ load with a linear speed of $0.035 \mathrm{~m} / \mathrm{s}$ on a radius of $5.5 \mathrm{~mm}$. The total test distance during which the coefficient of friction was determined was $100 \mathrm{~m}$. The wear measure was equal to volumetric loss of the sample occurred as a trace of abrasion as a result of sample and ball mating. For this purpose, a sample wear profile was measured on the circumference of the sample (in 12 places) using the Dektak 150 contact profilometer from Veeco Instruments. Volumetric loss was determined as the product of the average value of the sample wear trace and the circumference of the wear trace circle formed in the "ball-on-disc" test. Then the so-called wear factor $\mathrm{K}$, which, in addition to the volumetric loss, took into account the load and sliding distance used during the test (1)[19]:

$$
K=\frac{\text { Volume loss }}{\text { load } \times \text { sliding distance }}\left[\mathrm{mm}^{3} \mathrm{~N}^{-1} \mathrm{~m}^{-1}\right]
$$

A lower wear factor value $\mathrm{K}$ means greater abrasion resistance. Under the same test conditions, the resistance to cavitation erosion and abrasive wear of the reference sample made of AISI 304 steel were tested. Obtained results of coating resistance tests were compared with the results obtained for the reference sample. The relative normalized wear resistance $\mathrm{Ne}$ has been calculated. A higher value of the $\mathrm{Ne}$ coefficient means higher resistance to a given type of wear.

\section{Research results and their discussion}

\section{Characteristics of the tested coatings}

The roughness of the reference sample was $R a=0.1 \mu \mathrm{m}$, while the roughness of the $Z 2$ and $Z 3$ coatings measured in the state after the HVOF spraying was similar to each other and was $\mathrm{Ra}=5.6 \mu \mathrm{m}$ and $\mathrm{Ra}=4.7 \mu \mathrm{m}$. Figure 1 shows the surfaces of the tested coatings. The coatings were characterized by a lamellar structure typical for thermally sprayed materials. Photographs show lamellas, oxides and pores (Figure 1). The Z3 coating lamellas are characterized by the occurrence of cracks. The results of the analysis of the chemical composition of the coatings are presented in Table I. The Z2 coating contained nickel and cobalt, which according to literature [9] form a y solid solution with the structure of $\mathrm{fcc}$ and the intermetallic phase $\beta-(\mathrm{Co}, \mathrm{Ni}) \mathrm{Al}$, while the hardness of the coating is about $450 \div 550$ HV [9.2]. However, the Z3 coating contains large amounts of chromium, nickel and carbon. According to the literature data $[8,11,21]$, cermetal coatings of $\mathrm{Cr}_{3} \mathrm{C}_{2}$-NiCr type produced by the HVOF method may contain $\mathrm{Cr}_{3} \mathrm{C}_{2}, \mathrm{Cr}_{7} \mathrm{C}_{3}, \mathrm{Cr}_{2} \mathrm{O}_{3}$ and phases made of chromium and nickel, the matrix may contain amorphous phases and nanocrystalline metal grains. The hardness of $\mathrm{Cr}_{3} \mathrm{C}_{2}-\mathrm{NiCr}$ coatings is in the range of $850 \div 1150 \mathrm{HV}$ $[1,6,11]$. The oxidation and decarburization processes are unavoidable during thermal spraying, which is confirmed by the results of chemical analysis of coatings after spraying, contained in Table I and Figure 1. Oxygen has been identified on the surface of the coatings, which is consistent with the literature data [1] presented for $\mathrm{Cr}_{3} \mathrm{C}_{2}$-NiCr coatings produced by HVOF, moreover, oxidation of the coating material can lead to decarburization of $\mathrm{Cr}_{3} \mathrm{C}_{2}$ carbide and formation of $\mathrm{Cr}_{7} \mathrm{C}_{3}$ carbides [11]. In the case of coatings of the MCrAlY type, the forming aluminum oxides have a positive effect, because they provide thermal and chemical resistance of the coating [7].

\section{Results of wear resistance tests}

The diagrams shown in Figures $2 \div 4$ contain the results of abrasion and cavitation erosion resitance tests. The values of the registered coefficient of friction are given in Table II, while the values of the wear factor $K$ are shown in Figure 2.

A comparative analysis of friction coefficients showed that the coatings have a higher mean coefficient of friction than the reference material (Table II). It results directly from the method of surface preparation of the tested samples, i.e. the higher coating roughness after spraying in comparison to the roughness value of the ground surface of the reference sample. The obtained values of coefficient of friction for coatings after spraying are comparable to the values presented in the work of Cabral-Miramontes et al. [20] measured for coatings of the MCrAlY type sprayed with the HVOF method at different process parameters (torch-substrate distance).

The obtained results (Fig. 2) show that the Z3 coating was characterized by the highest abrasive wear resistance, while the Z2 coating obtained the lowest value of the $K$ coefficient (ie the highest abrasion resistance). It should be noted that the main application of $\mathrm{Cr}_{3} \mathrm{C}_{2}-\mathrm{NiCr}$ coatings (Z3) is the protection against abrasive wear of machine and equipment elements, in contrast to MCrAIY (Z2) coatings, which are mainly used as bond coating of TBC coatings.

The data presented in Figure 3 indicates that after 12 hours of testing, the $\mathrm{Z} 2$ and $\mathrm{Z} 3$ coatings were characterized by a higher cavitation resistance (less mass loss) than the reference sample. The $\mathrm{Z} 2$ coating was characterized by the highest resistance to cavitation erosion. Analysis of the relative

Table I. Results of chemical composition analysis in spots marked in Figure 1, SEM-EDS

\begin{tabular}{|c|c|c|c|c|c|c|c|c|}
\hline \multirow{2}{*}{$\begin{array}{c}\text { Oznaczenie } \\
\text { powłoki }\end{array}$} & \multicolumn{9}{|c|}{ Skład chemiczny, \% wag. } \\
\cline { 2 - 10 } & $\mathbf{N i}$ & Co & Cr & Al & Y & C & N & 0 \\
\hline Z2 & $21.2 \pm 0.5$ & $21.5 \pm 0.5$ & $14.1 \pm 0.3$ & $4.8 \pm 0.3$ & $0.6 \pm 0.1$ & $0.2 \pm 0.0$ & $9.0 \pm 0.6$ & $28.6 \pm 1.0$ \\
\hline Z3 & $8.3 \pm 0.4$ & - & $62.9 \pm 0.6$ & - & - & $1.1 \pm 0.1$ & $6.8 \pm 0.4$ & $20.8 \pm 0.7$ \\
\hline
\end{tabular}



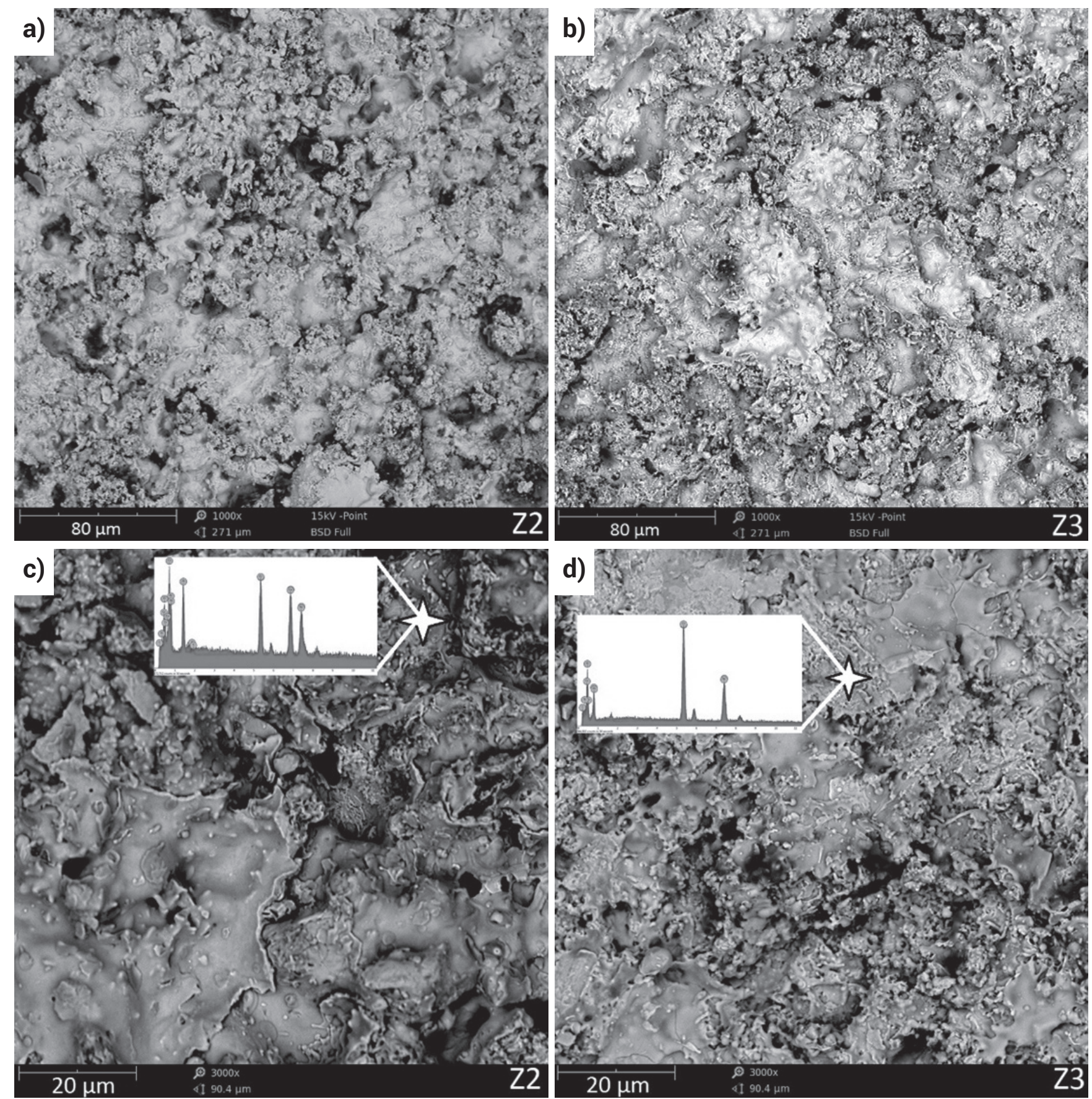

Fig. 1. Surface of as-sprayed Z2 (a) and Z3 (b) coatings and marked spot chemical analysis results Z2 (c) and Z3 (d), SEM-EDS

wear resistance value of $\mathrm{Ne}$ (Fig. 4) showed that the Z3 coating was characterized by a higher resistance to abrasion and cavitation than the reference sample. However, the highest resistance to cavitation erosion among the materials tested was obtained for the Z2 coating, which was also characterized by the lowest abrasive wear resistance, lower than that of AISI 304 steel.

The analysis of cavitation curves (Fig. 3) and the results of microscopic observations (Fig. 5) allows to observe different wear mechanisms for each of the tested materials.

Table II. Friction coefficient of tested coatings and reference steel

\begin{tabular}{|c|c|c|}
\hline Sample & $\begin{array}{c}\text { Average coefficient } \\
\text { of friction }\end{array}$ & Standard deviation \\
\hline 304 steel & 0.225 & 0.076 \\
\hline Coating Z2 & 0.584 & 0.057 \\
\hline Coating Z3 & 0.638 & 0.082 \\
\hline
\end{tabular}

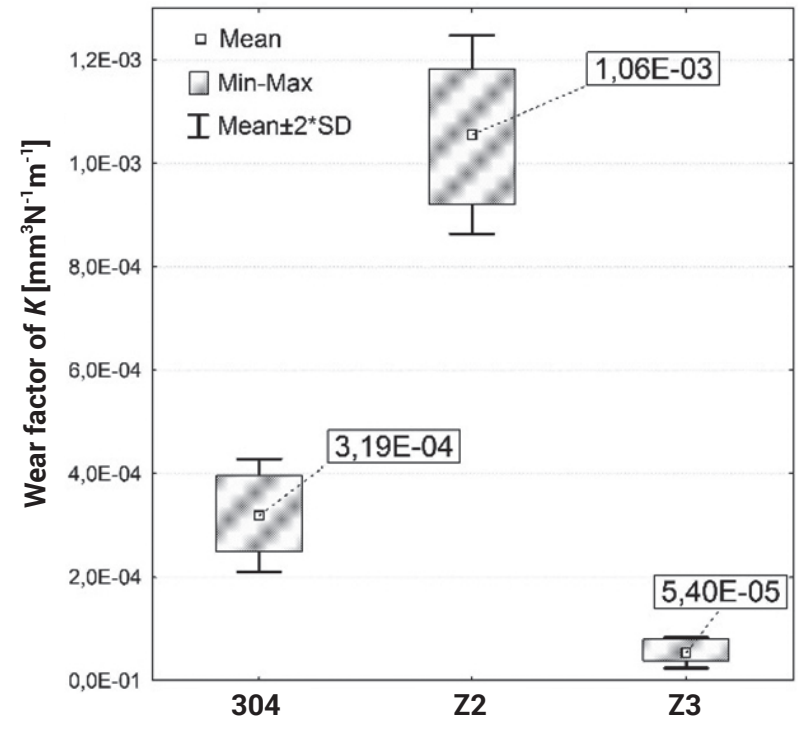

Fig. 2. Results of friction coefficient measurements for sprayed coatings and reference specimen 


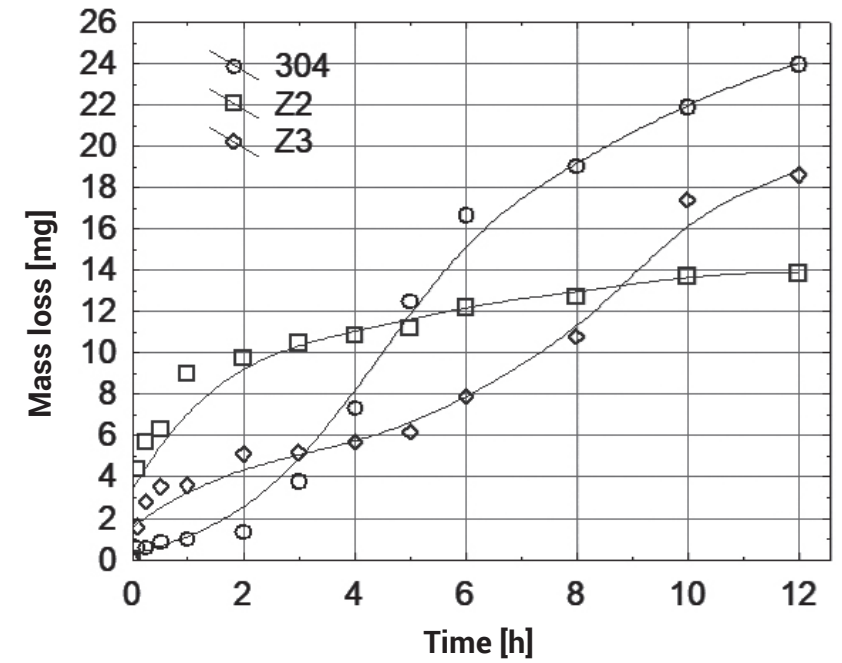

Fig. 3. Cavitation erosion curves of tested materials

Steel 304 shows cavitation erosion plot typical for metal alloys recorded in the literature $[17,22,23]$. However, the process of cavitation erosion of HVOF coatings began without a clear incubation period of cavitation erosion (characteristic for metal alloys). In the initial phase of erosion (up to about 1 hour of research), weakly fixed material particles were removed. After this period, the erosion rate of coatings is stable (Fig. 3). The lowest average erosion rate was recorded for the MCrAlY (Z2) metallic coating, while the largest for the $\mathrm{Cr}_{3} \mathrm{C}_{2}-\mathrm{NiCr}(\mathrm{Z3})$ cermet coating.

Figure 5 shows the surface of coatings observed at the same magnification for exposure times of 5 and 10 hours per cavitation. Based on the analysis of the surface of cavitation wear, it was found that the dominant process for cavitation erosion of the $\mathrm{Z} 2$ coating was the erosion of the material initiated by plastic deformation, and material removal began with erosion of the edge of the lamellas and in areas of porosity, which led to the formation and growth of cavitation pits. However, in the cavitation erosion mechanism of the Z3 coating, brittle cracking predominated leading to the spalling of relatively large portions of material and then uniform erosion of the surface of the coating (Fig. 5).

Comparing sample surfaces observed after different exposure times ( 5 and 10 hours, Fig. 5) and surfaces of coatings prior to cavitation tests (Fig. 1), it can be noticed that after

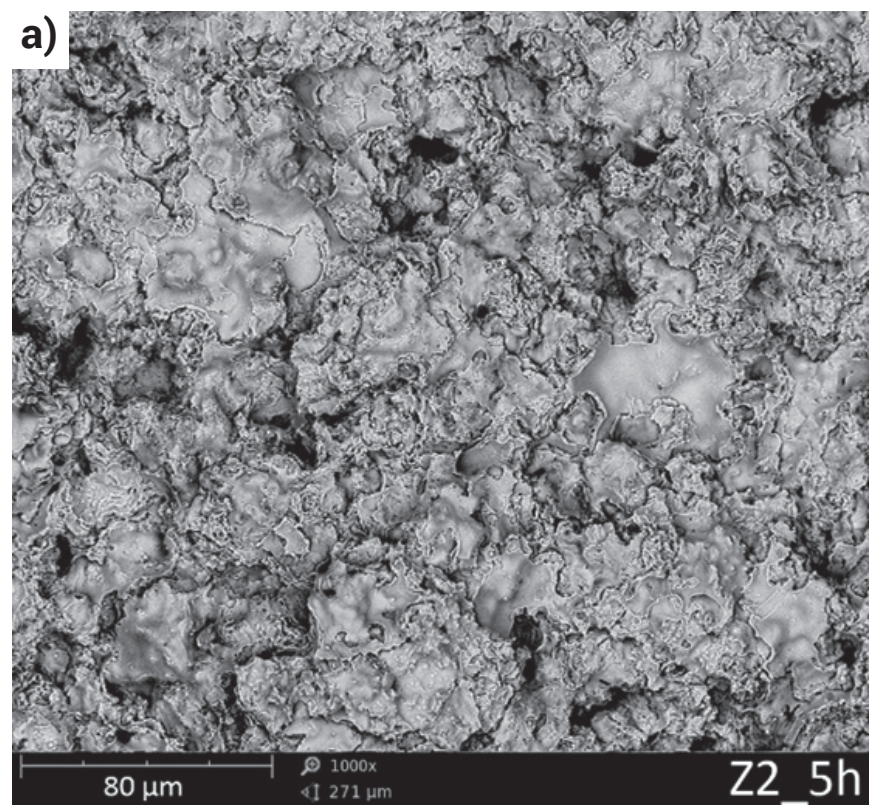

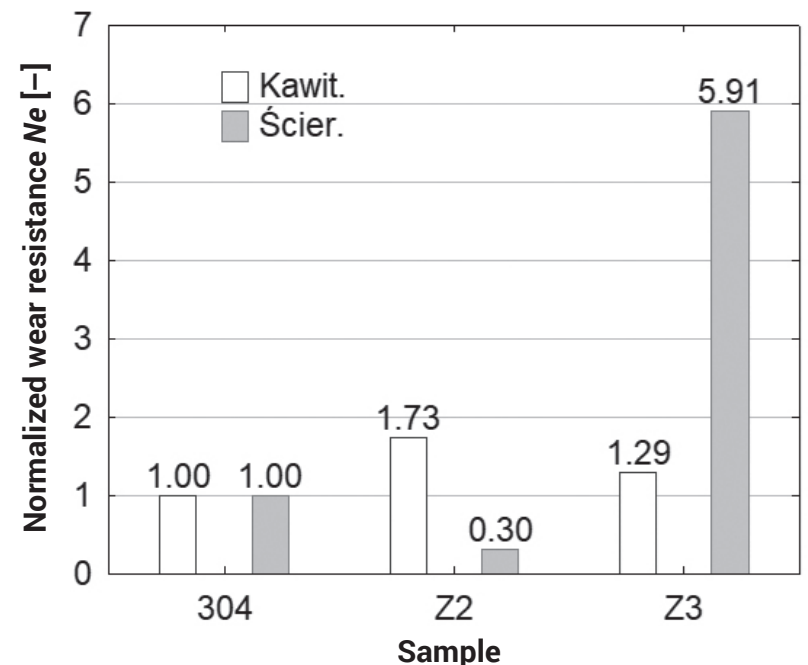

Fig. 4. Normalized wear resistance in relations to 304 steel

a longer exposure time it is possible to increase the pitting density (losses) in the Z2 coating and separating successive layers of the Z3 coating material over a larger surface (spalling off fragments of the coating). The phenomenon of cavitation erosion is a fatigue process. After 10 hours of cavitation exposure, the $Z 2$ coating has significantly lower surface degradation than the Z3 coating (Fig. 5). The MCrAlY coating (Z2) contained a metallic matrix consisting mainly of nickel, cobalt and chromium. $\mathrm{Cr}_{3} \mathrm{C}_{2}-\mathrm{NiCr}$ coatings (Z3) belong to the group of cermetal materials. The highest resistance to cavitation erosion of the $Z 2$ coating can be explained by the information presented in the literature for surfaced coatings [13.16 $\div 168.24]$. Namely, it has been found that padding welds on the basis of nickel and/or cobalt show a relatively high resistance to cavitation erosion, higher than materials with a multi-phase structure (e.g. cermet). This is due to the homogeneous structure of the matrix and the possibility of accumulating cavitation loads due to the plastic deformation of the metal matrix (composed of nickel and/or cobalt) and as a result of structural changes resulting in the curing of the material (cobalt-containing materials). The obtained research results suggest the possibility of applying $\mathrm{M}(\mathrm{Ni}, \mathrm{Co}) \mathrm{CrAlY}$ coatings as layers which increase the resistance to cavitation wear of machine and equipment elements, which requires further research.

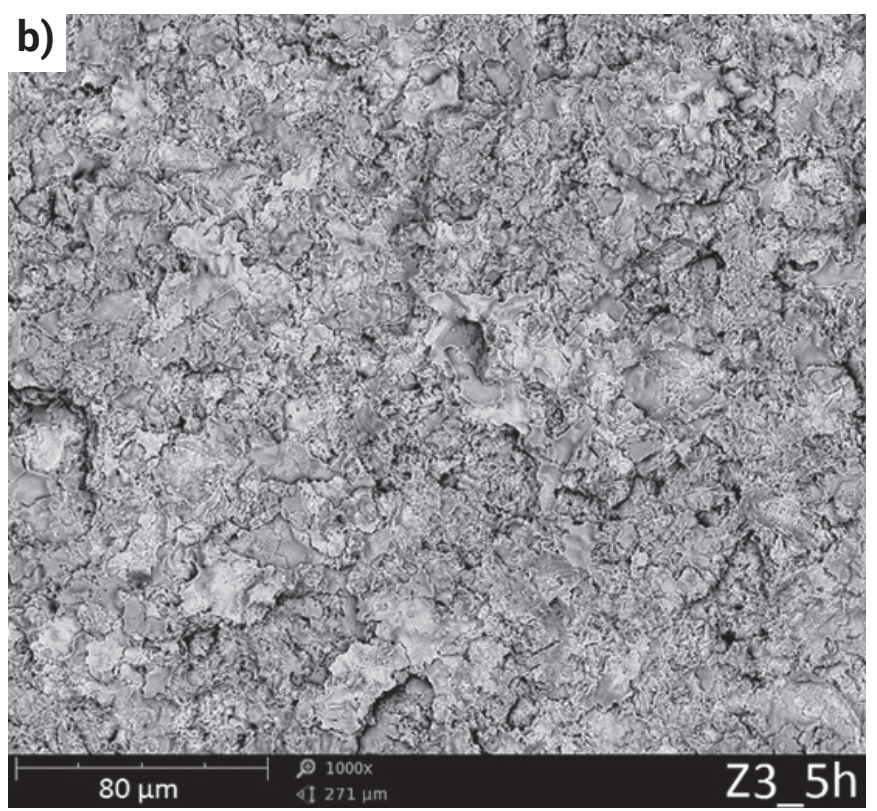

Fig. 5. Cavitation worn surfaces of $Z 2$ ( $a, c$ and $e$ ) and $Z 3$ (b, $d$ and $f$ ) coatings at 5 and 10 hours of exposition, SEM; (continuation of the Figure on the next page) 

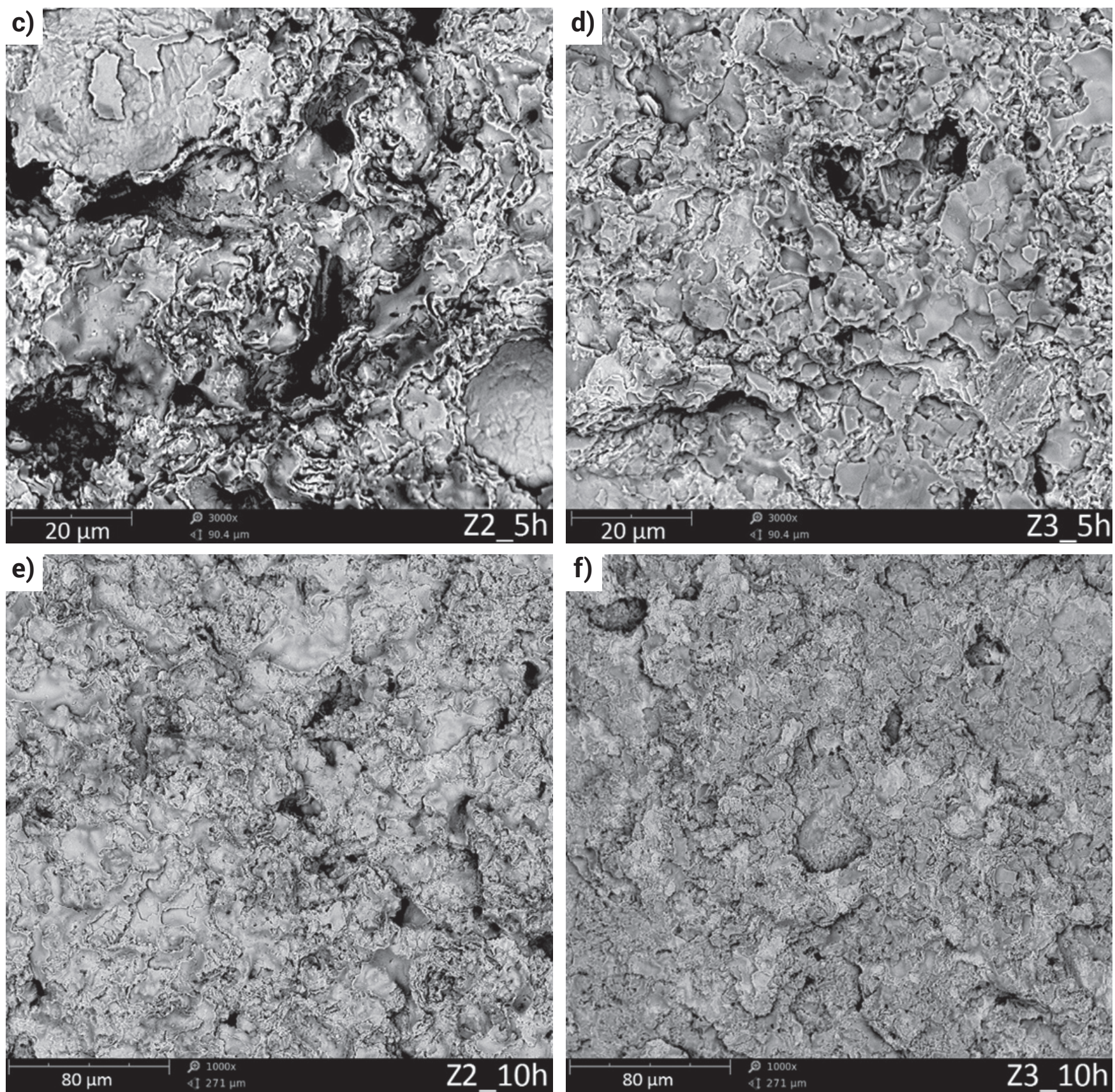

Cont. Fig. 5. Cavitation worn surfaces of $Z 2$ ( $a, c$ and e) and $Z 3$ (b, $d$ and $f$ ) coatings at 5 and 10 hours of exposition, SEM

\section{Conclusions}

The tests of resistance to cavitation and abrasion wear of HVOF type $\mathrm{M}(\mathrm{Ni}, \mathrm{Co}) \mathrm{CrAlY}$ and $\mathrm{Cr}_{3} \mathrm{C}_{2}-\mathrm{NiCr}$ coatings allow to present the following conclusions:

- The highest resistance to cavitation erosion was recorded for the $\mathrm{M}(\mathrm{Ni}, \mathrm{Co}) \mathrm{CrAlY}$ type coating.

- $\mathrm{Cr}_{3} \mathrm{C}_{2}$-NiCr coating has the highest resistance to abrasion.

- Coated HVOF coatings show greater resistance to cavitation erosion than reference stainless steel (grade 304).

- Compared to steel 304, the M(Ni,Co)CrAlY coating has a 3 times lower sliding wear resistance, and the $\mathrm{Cr}_{3} \mathrm{C}_{2}-\mathrm{NiCr}$ coating has more than 5 times higher abrasion wear resistance.

- HVOF coatings have obtained a similar value of the coefficient of friction, higher than the reference sample, which is related to the differences in roughness and hardness of the HVOF coatings and the reference steel.

- The mechanism of cavitation wear of $\mathrm{M}(\mathrm{Ni}, \mathrm{Co}) \mathrm{CrAlY}$ and $\mathrm{Cr}_{3} \mathrm{C}_{2}-\mathrm{NiCr}$ coatings differ from each other. The dominant process for cavitation wear of the $\mathrm{M}(\mathrm{Ni}, \mathrm{Co}) \mathrm{CrAlY}$ coating was the erosion of the material initiated by plastic deformation, and material removal began with erosion of the edge of the lamellas and in at the edges of pores, which led to the formation and growth of cavitation pits, whereas in the cavitation erosion mechanism of the $\mathrm{Cr}_{3} \mathrm{C}_{2}-\mathrm{NiCr}$ coating, brittle cracking predominated leading to the spalling of relatively large portions of material and then uniform erosion of the surface of the coating. 


\section{References}

[1] N. Jegadeeswaran, M.R. Ramesh, K.U. Bhat, Combating Corrosion Degradation of Turbine Materials Using HVOF Sprayed 25\% (Cr3C2-25(Ni20Cr)), International Journal of Corrosion (2013), DOI:10.1155/2013/824659.

[2] J.R. Davis, Handbook of Thermal Spray Technology, ASM International, OH, USA, 2004.

[3] A. Klimpel, Napawanie i natryskiwanie cieplne: technologie, WNT, 2009.

[4] K. Szymański, A. Hernas, G. Moskal, H. Myalska, Thermally sprayed coatings resistant to erosion and corrosion for power plant boilers - A review, Surface and Coatings Technology 268 (2015), 153-164, DOI:10.1016/j.surfcoat.2014.10.046.

[5] P. Zhang, J.H. Jiang, A.B. Ma, Z.H. Wang, Y.P. Wu, P.H. Lin, Cavitation Erosion Resistance of WC-Cr-Co and $\mathrm{Cr} 3 \mathrm{C} 2-\mathrm{NiCr}$ Coatings Prepared by HVOF, Advanced Materials Research (2007), DOI:10.4028/www.scientific.net/ AMR.15-17.199.

[6] G. Taillon, F. Pougoum, S. Lavigne, L. Ton-That, R. Schulz, E. Bousser, S. Savoie, L. Martinu, J.-E. Klemberg-Sapieha, Cavitation erosion mechanisms in stainless steels and in composite metal-ceramic HVOF coatings, Wear. 364-365 (2016), 201-210, DOI:10.1016/j.wear.2016.07.015.

[7] P. Zhang, R. Lin Peng, X.-H. Li, S. Johansson, P. Zhang, R. Lin Peng, X.$\mathrm{H}$. Li, S. Johansson, Investigation of Element Effect on High-Temperature Oxidation of HVOF NiCoCrAIX Coatings, Coatings 8 (2018), 129, DOI:10.3390/coatings8040129.

[8] W. Zhou, K. Zhou, Y. Li, C. Deng, K. Zeng, High temperature wear performance of HVOF-sprayed Cr3C2-WC-NiCoCrMo and $\mathrm{Cr} 3 \mathrm{C} 2-\mathrm{NiCr}$ hardmetal coatings, Applied Surface Science 416 (2017), 33-44, DOI:10.1016/j.apsusc.2017.04.132.

[9] S. Saeidi, K.T. Voisey, D.G. McCartney, Mechanical Properties and Microstructure of VPS and HVOF CoNiCrAlY Coatings, J Therm Spray Tech. 20 (2011), 1231-1243, DOI:10.1007/s11666-011-9666-5.

[10] S. Lavigne, F. Pougoum, S. Savoie, L. Martinu, J.E. Klemberg-Sapieha, R. Schulz, Cavitation erosion behavior of HVOF CaviTec coatings, Wear. 386-387 (2017), 90-98, DOI:10.1016/j.wear.2017.06.003.

[11] S. Hong, Y. Wu, Q. Wang, G. Ying, G. Li, W. Gao, B. Wang, W. Guo, Microstructure and cavitation-silt erosion behavior of high-velocity oxygen-fue (HVOF) sprayed $\mathrm{Cr} 3 \mathrm{C} 2-\mathrm{NiCr}$ coating, Surface and Coatings Technology. 225 (2013), 85-91, DOI:10.1016/j.surfcoat.2013.03.020.

[12] M. Oksa, E. Turunen, T. Suhonen, T. Varis, S.-P. Hannula, M. Oksa, E. Turunen, T. Suhonen, T. Varis, S.-P. Hannula, Optimization and Characterization of High Velocity Oxy-fuel Sprayed Coatings: Techniques, Materials, and Applications, Coatings. 1 (2011), 17-52, DOI:10.3390/coatings 1010017.

[13] M. Szala, T. Hejwowski, Cavitation Erosion Resistance and Wear Mechanism Model of Flame-Sprayed Al203-40\%TiO2/NiMoAl Cermet Coatings, Coatings. 8 (2018) 254, DOI:10.3390/coatings 8070254
[14] L. Łatka, M. Szala, M. Michalak, P. Sokołowski, T. Pałka, Impact of atmospheric plasma spray parameters on cavitation erosion resistance of Al203-13\%TiO2 coatings, Acta Physica Polonica A. w druku (2019).

[15] A. Kumar, J. Boy, R. Zatorski, L.D. Stephenson, Thermal spray and weld repair alloys for the repair of cavitation damage in turbines and pumps: A technical note, (2005) 177-182, http://link.springer.com/article/10.1361/ 10599630523737 (accessed June 12, 2013).

[16] M. Szkodo, Erozja kawitacyjna materiałów konstrukcyjnych metalowych, Wydawn. Politechniki Gdańskiej, 2008.

[17] M. Szala, Powłoki zwiększające odporność na erozję kawitacyjną elementów maszyn i urządzeń, Rozprawa doktorska, Politechnika Lubelska, Lublin, Polska, 2016.

[18] M. Szala, T.J. Hejwowski, Zwiększanie odporności kawitacyjnej stopów metali przez napawanie powłok, Welding Technology Review (2015), vol. 87 (9), 56-60.

[19] M. Walczak, D. Pieniak, M. Zwierzchowski, The tribological characteristics of SiC particle reinforced aluminium composites, Archives of Civil and Mechanical Engineering 15 (2015), 116-123, DOI:10.1016/j.acme. 2014.05.003.

[20] J.A. Cabral-Miramontes, C. Gaona-Tiburcio, F. Almeraya-Calderón, F.H. Estupiñan-Lopez, G.K. Pedraza-Basulto, C.A. Poblano-Salas, Parameter Studies on High-Velocity Oxy-Fuel Spraying of CoNiCrAlY Coatings Used in the Aeronautical Industry, International Journal of Corrosion (2014), DOI:10.1155/2014/703806.

[21] M. Xie, Y. Lin, P. Ke, S. Wang, S. Zhang, Z. Zhen, L. Ge, M. Xie, Y. Lin, P. Ke, S. Wang, S. Zhang, Z. Zhen, L. Ge, Influence of Process Parameters on High Velocity Oxy-Fuel Sprayed Cr3C2-25\%NiCr Coatings, Coatings 7 (2017), 98, DOI:10.3390/coatings 7070098 .

[22] M. Szala, Application of computer image analysis software for determining incubation period of cavitation erosion - preliminary results, 15 (2017), 06003, DOI:10.1051/itmconf/20171506003.

[23] J. Chmiel, R. Jasionowski, D. Zasada, Cavitation Erosion and Corrosion of Pearlitic Gray Cast Iron in Non-Standardized Cavitation Conditions, Solid State Phenomena (2015), DOI:10.4028/www.scientific.net/SSP.225.19.

[24] S. Hattori, N. Mikami, Cavitation erosion resistance of stellite alloy weld overlays, Wear. 267 (2009), 1954-1960. DOI:10.1016/j.wear.2009.05.007.

[25] M. Szala, T. Hejwowski, I. Lenart, Cavitation erosion resistance of Ni-Co based coatings, Adv. Sci. Technol. Res. J. 8 (2014), 36-42, DOI:10.12913/ 22998624.1091876 